\title{
Glaciers Amount and Extent Change in the Dolra River Basin in 1911-1960-2014 Years, Caucasus Mountains, Georgia, Observed with Old Topographical Maps and Landsat Satellite Imagery
}

\author{
Levan G. Tielidze ${ }^{1}$, Nino Chikhradze ${ }^{1,2}$, David Svanadze ${ }^{3}$ \\ ${ }^{1}$ Vakhushti Bagrationi Institute of Geography, Ivane Javakhishvili Tbilisi State Uniersity, Tbilisi, Georgia \\ ${ }^{2}$ llia State University, Tbilisi, Georgia \\ ${ }^{3}$ Department of Geography, Faculty of Exact \& Natural Sciences, Ivane Javakhishvili Tbilisi State University, \\ Tbilisi, Georgia \\ Email: levan.tielidze@tsu.ge, levani.tielidze@gmail.com
}

Received 14 March 2015; accepted 15 May 2015; published 18 May 2015

Copyright $@ 2015$ by authors and Scientific Research Publishing Inc.

This work is licensed under the Creative Commons Attribution International License (CC BY).

http://creativecommons.org/licenses/by/4.0/

(c) (i)

\section{Abstract}

The article presents the changes in the number and area of the Dolra River basin glaciers during the last century in connection with the climate elements. Dolra River basin is located in the southern slope of the Central Caucasus, in the territory of Zemo Svaneti and joins the Enguri River basin, which in its turn is the main center of the contemporary glaciation in Georgia. During the study, we used the 1:42,000 scale topographic maps of the 19th century, which were drawn up during the first topographic survey by using the plane-table surveying method. Also, we used the catalog of the glaciers of the southern slope of the Caucasus compiled on the basis of the 19th century maps in 1911 by a well-known researcher of the Caucasus K. Podozerskiy. In order to identify the area and number of the glaciers of the $60 \mathrm{~s}$ of the 20th century, we used the work of R. Gobejishvili-the Georgian glaciologist of the 20th-21st centuries, composed on the basis of 1:50,000 scale topographic maps of 1960. The data of 2014 have been obtained by the Landsat aerial images of L8 OLI/TIRS (Operational Land Imager and Thermal Infrared Sensor) taken in August 2014. In the mentioned study, except of the old topographic maps and aerial images, we used the climate information that we have collected from Mestia weather stations (Mestia is the regional center of Zemo Svaneti, where the only operating weather station is located at present). Along with the dynamics of glaciers, the course of the air temperature and atmospheric precipitation has been identified in the 20th century and in the beginning of the 21st century. 


\section{Keywords}

\section{Glaciers Dynamic, Remote Sensing, Glaciers of Georgia-Caucasus Mountains, Kvishi, Dolra and Ushba Glaciers, Climate Change in Georgia}

\section{Introduction}

Glaciers are one of the best indicators of climate change and a nearly global retreat of glaciers has been recently reported [1] [2]. Moreover, glaciers respond to changes in climate, translating the climatic signal into clearly observable changes in the landscape. Quantitative information on glacier fluctuations over previous centuries therefore provides long-term context for recently observed climatic changes of the last several decades [3]-[5]. Measurements of glacier fluctuations can also be used to estimate the glacier contribution to sea-level rise [6]-[8], and to assess the effect of glacier changes on mountain hydrology and fresh water availability [9]-[12].

Mountain glaciers are a product of climate and are important environmental components of local, regional and global water cycles. Glaciers are sources of beauty in the mountain landscapes and, in many cases, have been among the primary agents responsible for forming these landscapes [13] [14].

One region where alpine glaciers exist is the Caucasus Mountains [15]. High Caucasus range is favorable for the existence of glaciers in Georgia. There are places in certain sections of the range, where its height exceeds 3000 - 3500 meters, by foreseen of the relief and climatic conditions, where the accumulation of solid atmospheric precipitation fallen in the cold period occurs during many years [16].

At present, there are 637 glaciers in Georgia. Contemporary glaciers are mainly concentrated in the Enguri, Rioni, Kodori and Tergi river basins. Main centers of glaciation are linked to upraised Caucasian watershed range and Kazbegi massif. There are also the separate centers in the branch ranges of the Caucasus: Bzipi, Kodori, Samegrelo, Svaneti, Lechkhumi, Khevsureti, Pirikita and others. The glaciers of all expositions can be found in Georgia today, and among the morphological types the following can be distinguished: compound-valley, simplevalley (with one or multi-cameral firn), cirque-valley, cirque-hanging, hanging and cirque glaciers [16] [17].

\section{Stady Area}

One of the main centres of mountain glaciation in Europe is the Greater Caucasus Mountains located between the Black and Caspian Seas in the densely populated southwest of Russia and Georgia [18]. The Greater Caucasus mountain range is streatched along the territory of Georgia at about $750 \mathrm{~km}$, and according to the morphological and morphometric characteristics it is divided into the three parts—Western, Central and Eastern [16] [19].

Dolra River basin is located on the southern slope of the Central Caucasus range (Figure 3(a)). The Dolra gorge has a trough form at a whole length. There is a well preserved cirque in its headrwaters, which is originated due to impact of glaciations in Late Pleistocene. This vast cirque was a feeding area of the old glciation in Dolra. United ice tongue flowed in the Enguri gorge in Wurm [20].

In Mestia, humid climate with cold winter and long, chilly summer has been formed. Based on the observations of 1936-1960 an average annual temperature for this territory was $+5.7^{\circ} \mathrm{C}$, the coldest month (January) average was $-6.0^{\circ} \mathrm{C}$. The warmest month (July) average was $+16.4^{\circ} \mathrm{C}$, the absolute minimum $-35^{\circ} \mathrm{C}$, while the absolute maximum was $+35^{\circ} \mathrm{C}$. The sum of active temperatures (above $+10^{\circ} \mathrm{C}$ ) was $2039^{\circ} \mathrm{C}$ degrees, the average annual air relative humidity was $75 \%$, the total annual amount of precipitation was $918 \mathrm{~mm}$, with a maximum monthly sum which usually fell in October and was $95 \mathrm{~mm}$, while the minimum fell in February $(61 \mathrm{~mm})$. The average annual wind speed equaled $1.1 \mathrm{~m} / \mathrm{s}$. Mostly the northern and the south-western winds were prevalent in the surrounding area [21].

In the Dolra River basin the glaciers are located on the eastern slope of the Kvishi range, on the northern slope of the Baki range and on the southern slope of the Greater Caucasus between the Mount Donghuzorun (4454 m) and Mount Ushba (4700 m). Share of the glaciers of the Dolra River basin is $14.86 \%$ of the total number and $15.17 \%$ of the total area of the glaciers of the Enguri River basin.

Valley-type glaciers create main background for glaciation in the Dolra River basin. The Kvishi glacier with the area of $7.45 \mathrm{~km}^{2}$ and the Dolra glacier with the area of $5.48 \mathrm{~km}^{2}$ are distinguished by their special sizes. $38.15 \%$ of the total area of the glaciers of the Dolra River basin is the share of the above mentioned glaciers. 
The second place occupy the compound-valley glaciers by their area $\left(7.74 \mathrm{~km}^{2}\right)$. There are only two glaciers of such type (northern Ushba and southern Ushba). Glaciers of other morphological types occupy small area (Figure 1).

In the Dolra River basin the glaciers of overall southern exposition prevail by their number and area, which are mainly distributed in the Baki range of latitutdinal direction (Figure 2).

Detail description of the glaciers of the Dolra River basin have V. Rutkovskaia (1933), P. Kovalyov (1961), G. Kurdghelaidze (1966), R. Khazaradze (1968), R. Gobejishvili (1995) and others.

\section{Data Sources and Methods}

Maps and the aerial images of different years are needed to describe the dynamics of glaciers. 1:42,000 large scale topographic maps of the Caucasus were compiled by the plain table surveying method in 1880-1890. In 1911 K.I. Podozerskiy published the first inventory of the Caucasus glaciers, compiling data on the lengths and areas of all of the glaciers [22]. The data by K. Podozerskiy are obtained just from the maps of 1880-1890; detailed analysis of the data showed that there are many defects in the shape of the glaciers of that time, particularly the inaccessible firn valleys of the valley glaciers are depicted incorrectly. Naturally, this fact will cause a slight error in the identification of precise areas of the glaciers of that time, but in reality there exist no other data about the mentioned period and these maps are the most reliable source for us.

The old topographic maps were replaced with the new ones in 1960, when during the period of the former Soviet Union the 1:50,000 scale maps were published with the depiction of quite precise contours of the glaciers of the Caucasus. R. Gobejishvili gave us new statistical information about the glaciers of Georgia [23].

We made a geo-referencing of the maps of the both periods by using the GIS program, and registered them in the modern coordinate system (Universal Transverse Mercator, zone 38-North on the WGS84 ellipsoid).

In order to identify the number and area of the glaciers we use remote sensing method, which is an established way of monitoring the changes in glacier area and positions of glacier snouts.

The Landsat L8 OLI/TIRS (Operational Land Imager and Thermal Infrared Sensor) (USGS) satellite images, which are taken in August 3, 2014 by using the GIS, we put them in 7-5-3 band sequence and obtained the desired image.

In parallel of the dynamics of the glaciers it is important for us to identify the course of the atmospheric precipitation and air temperatures in the high mountain regions of Georgia during the same period. For this we use

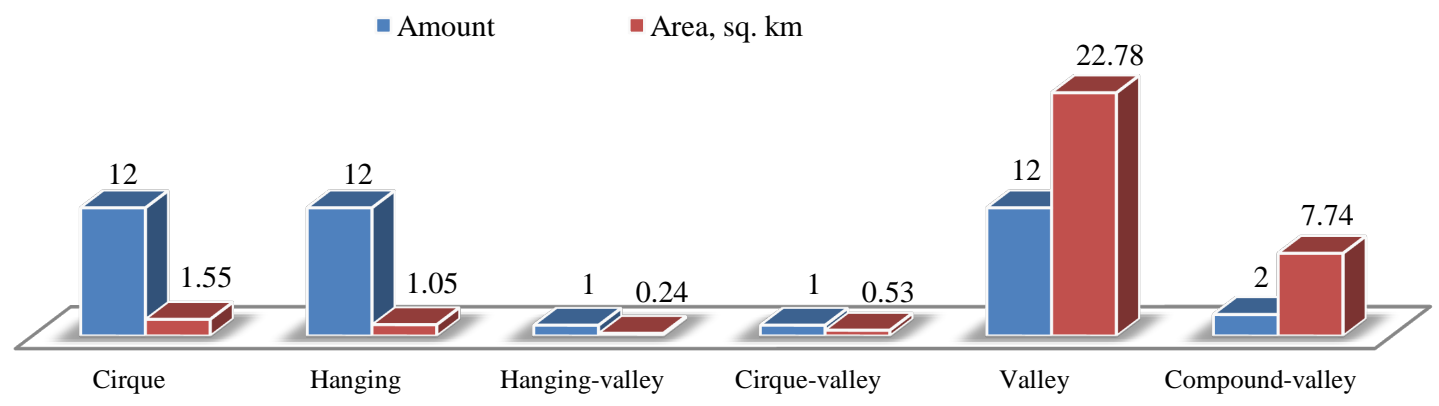

Figure 1. Distribution of the glaciers in the Dolra River basin according to the morphological types.

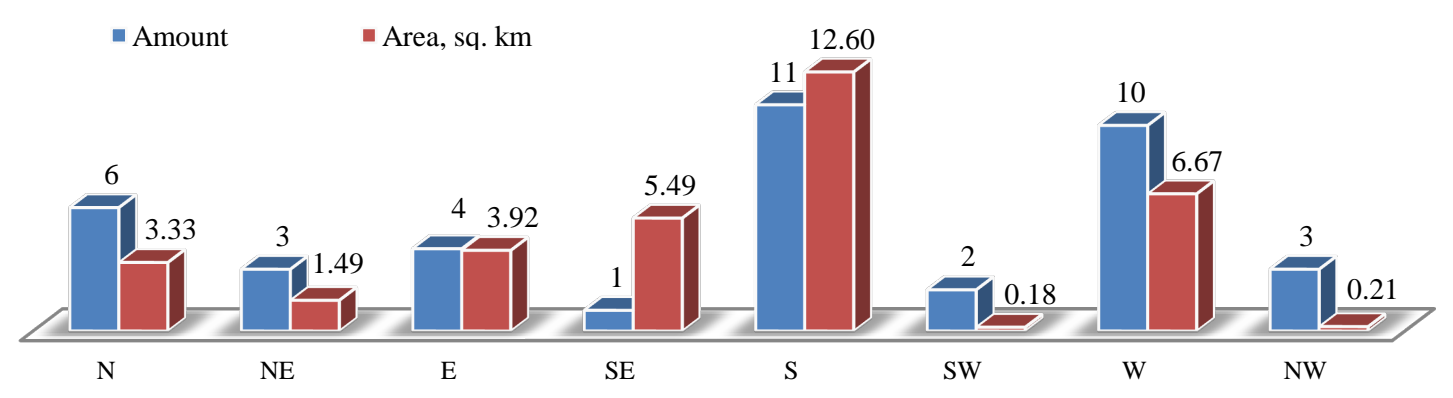

Figure 2. Distribution of the glaciers in the Dolra River basin according to the exposition. 
the meteorological data of the high mountain regions of Georgia such as Mestia-data of 1906-2013 (1440 m above sea level). The mentioned data has been transferred from the mean monthly into the mean annual and has been linked to the dynamics of the glaciers.

From 2004 through 2014, every summer season we organize expeditions to almost to all of the glacial basins of the Caucasus. By using the GPS we survey the ice tongues and record their dynamics. In order to obtain a high accuracy of the data, we use GPS data along with the old topographic maps and the Landsat space images.

\section{Results}

By K. Podozerskiy (1911) there were 16 glaciers with the area of $48.5 \mathrm{~km}^{2}$ [24]. By the data of 1960 the number of the glaciers has increased up to 28 but their areas almost have not been changed-48.6 $\mathrm{km}^{2}$ [24]. When we compared the topographical maps of the both periods, the analysis showed that the firn valleys are very incorrectly depicted on the old topographical maps. Namely, it concerns to the largest valley glaciers Kvishi, Dolra and Ushba. There are 40 glaciers there by the data of 2014 with the total area of $33.9 \mathrm{~km}^{2}$.

As the main center of the glaciation in the Dolra basin present the glaciers of Kvishi, Dolra and Ushba, we will just focus on their dynamics in connection with the climatic elements.

According to the data of 1911 the Kvishi glacier was the compound-valley largest glacier in the Dolra basin, with an area of $34.3 \mathrm{~km}^{2}$ (Figure 3(b)). In 1960 the area of the Kvishi glacier was $19.1 \mathrm{~km}^{2}$. It was formed by joining several powerful glaciers and was a glacier of the compound-valley type. During the expedition in 1977 (R. Gobejishvili), the Kvishi glacier was already split and was consisted of four independent glaciers-Kvishi, Ladevali, Tsalgmili and Lakra. In the aerial image of 2014 it is well seen that there are already five glaciers there-Ladevali (Figure 3(c)), southern and northern Tsalgmili (Figure 3(d) and Figure 3(e)), Lakra (Figure 3(f)) and Kvishi (Figure 3(g)). This is caused by the fact that after 1977 due to the melting the Tsalgmili glacier was divided into two parts (northern Tsalgmili and the southern Tsalgmili). The ice tongues of the Kvishi basin glaciers are separated from each other by $\sim 0.3-0.5 \mathrm{~km}$ and experience intensive retreating. It should be noted that if at early times the Kvishi glacier tongue was covered by a very thick loose material (this factor that has always had a large dead glacier), today the ice tongues of the individual glaciers are characterized by nearly pure surfaces.

Dolra glacier is a valley glacier of south-eastern exposition. As the old topographic map of 1887 shows, the Dolra glacier contour is depicted quite incorrectly. Respectively, its area $\left(7.9 \mathrm{~km}^{2}\right)$ is wrong in the catalog of K. Podozerskiy (1911). In 1960 glacier area was $8.0 \mathrm{~km}^{2}$. In $2014-5.5 \mathrm{~km}^{2}$. In 1960 the glacier was ended with the ice tongue hanged from the ledge, and it experienced strong mechanical destruction. However, compared to the

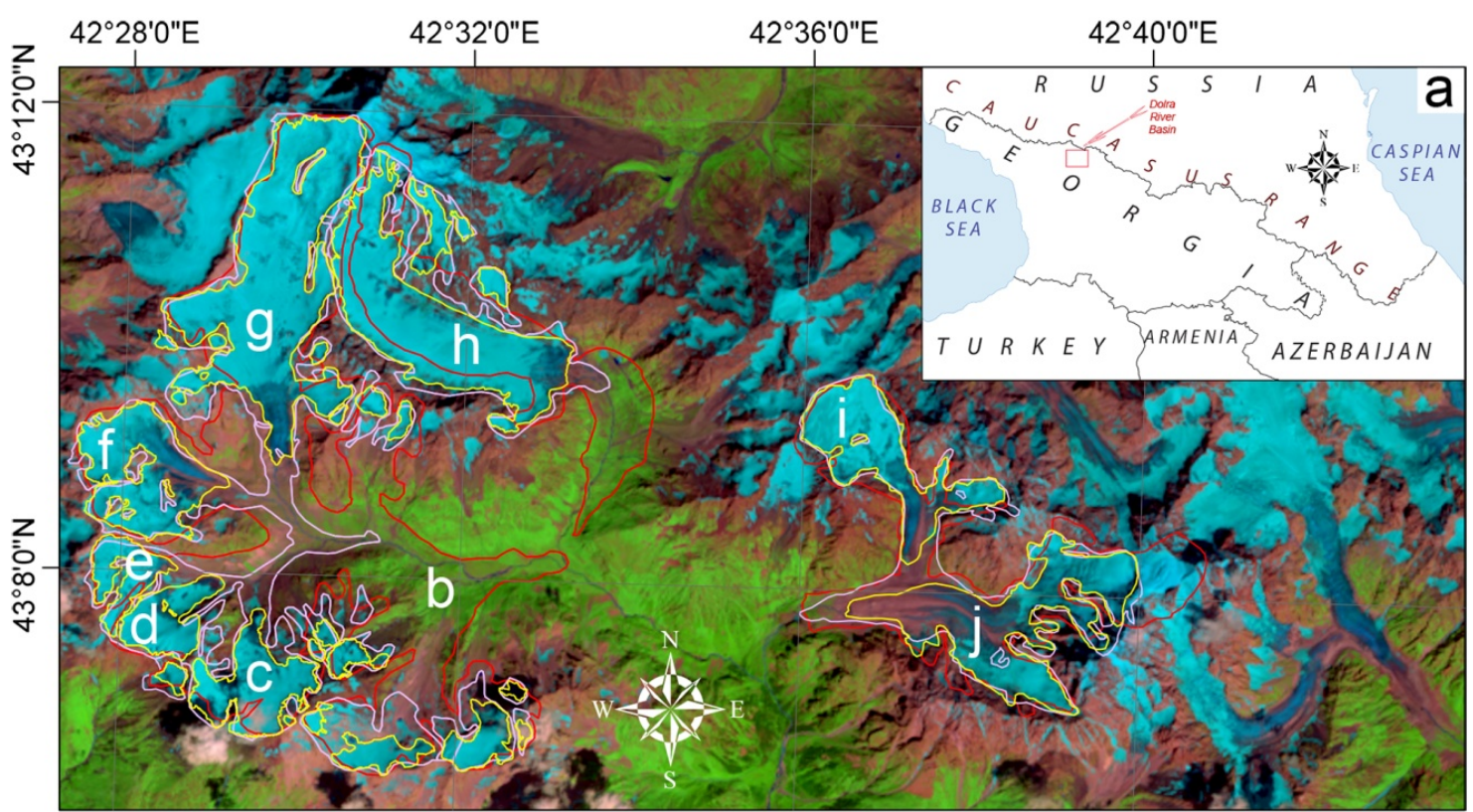

Figure 3. (a) Location of the Dolra River Basin and retreat of Kvishi (b); Dolra (h) and Ushba (i); (j) glaciers in 19111960-2014. 
other glaciers of the Greater Caucasus, the big indicator of retreating in the Dolra glacier has not been recorded (Figure 3(h)). One of the factors conditioning this case can be the fact the Dolra ice tongue ends at the highest elevation - 2940 meters above sea level as compared to the glaciers of about the same size in the Enguri River basin.

Well expressed lateral stade and microstade moraines go along the both slopes of the Dolra River gorge below the ledge, which allows us to discuss its dynamics after the Fernau stage.

Ushba glacier contour like the Dolra glacier contour is depicted slightly incorrectly in the catalog of K. Podozerskiy; in particular, the firn valley contour of the left flow goes beyond the real firn valley boundaries and includes the larger area. As for the glacier tongue, compared with the ice-tongue depicted in the topographic map of 1960, is slightly shorter, which in our opinion is not true. According to the catalog of K. Podozerskiy (1911) the glacier area was $11.3 \mathrm{~km}^{2}$ and it was a compound-valley type of glacier.

Northern Ushba (Figure 3(i)) and southern Ushba (Figure 3(j)) glaciers were presented as one, compoundvalley glacier in 1960 also, its area was $9.5 \mathrm{~km}^{2}$. The glacier was consisted of four flows. Two of the main lefthand flows were flowed down from the Ushba slopes, and the righthand two flows - from the Shkhelda slopes. The glacier was of overall western exposition. Its ice tongue was ended at a height of 2400 meters above sea level.

We had the last expeditions to the Ushba glacier in 2012, 2013 and 2014, during which we made a marking and visual inspection of the glacier tongue. In order to specify the data we compared the materials obtained during the field survey with the latest aero-space images.

Recent data prove that the compound-valley glacier is divided and is presented as two compound-valley glaciers (each consisting of two flows). As it can be seen from the satellite images, its division would have happened in the years of 2000-2005, because in the space image of 2000 there can be still observed a little contact, but in the image of 2014, the northern flow is already distanced from the southern flow. Thus, today we have two glaciers. Out of them, the main flow is the southern Ushba anyway, its area is $4.7 \mathrm{~km}^{2}$, while the area of the northern Ushba is $3.0 \mathrm{~km}^{2}$. As a whole, it appears that the glacier area was reduced by $18.6 \%$ in the years of 1960-2014 (Figure 3(i) and Figure 3(j)).

Three medial moraines go along the ice tongue surface (from the middle section) of the southern Ushba glacier, which are adjacent to each other in the last part of the glacier tongue and cover its surface by a powerful loose material; in spite of it, the medial moraine do not lose their morphological signs due to depressions among them.

Stade moraines of the Ushba glacier are weakly expressed due to the existence of a high ledge there. They are comparatively well presented in the front section of the ice tongue. Today the ice tongue ends at a height of $2600 \mathrm{~m}$ above sea level.

Water stream flowing from the Ushba glacier overflows the ledge in about one kilometer and creates one of the most beautiful waterfalls in Georgia, the Shtugra waterfall.

\section{Discussion}

In addition to the old topographic maps and modern space images it is important to take into account the climatic conditions during the study of the glacier dynamics. For this purpose we use the atmospheric precipitation and air temperature data of Mestia meteorological station [25] from 1906 to 2013 inclusive. The mentioned weather station is located in the north-east from the Dolra basin at about 20 kilometers away at a height of $1440 \mathrm{~m}$ above sea level and at present it is the only active weather stations in the Zemo Svaneti region.

Mean monthly air temperature data was transferred into the mean annual data. Because the changes in the number and area of the glaciers are given in the two periods, for more precision the air temperatures were divided into the two periods as well, in the periods of 1906-1960 and 1961-2013.

The course of the mean annual temperatures of 1906-1960 shows that the trend is negative, or the overall reduction in the air temperature is observed (Figure 4). If we compare the mentioned data with the changes in the number and the area of the glaciers, we will see that the number of the glaciers has increased from 16 to 28 in the period of 1911 to 1960, while the area is almost the same (Figure 8). Again in this case we are dealing with a slight inaccuracy which was made during the compilation of the old maps of K. Podozerskiy. It is natural, that without changing in the area of the glaciers their number would not be able to grow. As for the air temperature, it was identified that the mean multiannual air temperature of $1906-1960$ is $+5.9^{\circ} \mathrm{C}$. When this data was compared with the mean secular temperature, we got no difference, because the mean secular temperature is exactly $+5.9^{\circ} \mathrm{C}$. 


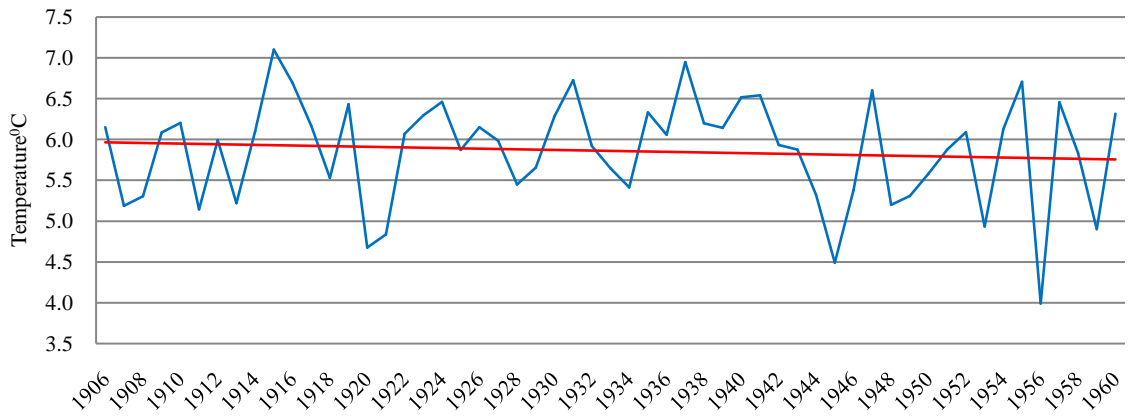

Figure 4. The course of the Mestia meteorological station's mean annual air temperatures in 1906-1960.

As for the period 1960-2014, the temperature trend is positive here, or we are dealing with the mean annual temperature rise (Figure 5). The data of this period is high by $+0.1^{\circ} \mathrm{C}\left(+6.0^{\circ} \mathrm{C}\right)$ compared to the mean secular temperature. If we compare these data in comparison with the changes in the number and area of the glaciers, we will see that within the same period the area of the glaciers has reduced from $48.6 \mathrm{~km}^{2}$ to $33.9 \mathrm{~km}^{2}$, while the number of the glaciers has increased from 28 to 40 (Figure 8). Increase in the number of the glaciers is mostly connected with the reduction of the Kvishi glacier. After its degradation, from 1960 to the present day, one glacier of compound-valley type was replaced by about 15 small size simple valley and even smaller cirque type of glaciers. In addition, the Ushba glacier was divided into two parts after 1960 and now it is in the form of two glaciers. And around the Dolra glacier there are the other three small glaciers presented.

It is interesting to compare the temperatures and annual precipitation course with the glaciers changing. Unfortunately, we do not have the data on atmospheric precipitation over the past century. The mentioned data we have only in the years of 1961-2010 (Figure 6).

The figure shows that the precipitation trend is positive, but if we take the precipitations by individual months, the trend is negative here, for example the December month precipitations (Figure 7). In addition, as since 1960 to 2013 the air temperatures trend is clearly positive, it is likely that in some cases the places where the precipitation was falling as snow, today falls as rain. But it is impossible to tell it with preciseness, because we do not have such detailed data on precipitation.

\section{Conclusions}

Finally, as a result of the conduced research, we conclude that in the years of 1911-1960 the number of the glaciers in the Dolra River basin was increased by $42 \%$ but the area remained almost the same (Figure 8 ), which is stipulated due to the mistakes made in the old topographic maps. The course of the air temperatures in the same period is characterized by a negative trend.

As for the years of 1960-2013, the area of the glaciers was reduced by $30.2 \%$ in this period, and their number was increased by $42.9 \%$ (Figure 8 ). The air temperature trend is positive in the same period and the mean air temperature is higher than $+0.1^{\circ} \mathrm{C}$ than the mean secular temperature. The atmospheric precipitation trend is positive as well, but the December month is characterized by decrease in precipitation.

The increasing of the glaciers number in parallel with the reduction of their area in the Dolra River basin in the last 54 years does not correspond to the common course of the similar data of the other river basins on the southern slope of the Caucasus in the same period. During the last half century, nearly in all of the river basins the decreasing of the glaciers number in parallel with the reduction of their area is observed (with the exception of only a few of the river basins, where the decreasing of the glaciers number in parallel with the reduction of their area is not observed, for example the Bzipi River basin, where there were 18 glaciers in 1960 and their number is still the same by the data of 2014). Even in the Enguri River basin, the basin of which the Dolra River represents, the area of glaciers was reduced by $32.8 \%$ in $1960-2013$, and their number was decreased by $10.0 \%$.

The reason of the simultaneous reduction in the number and area of the glaciers on the southern slope of the Caucasus in the mentioned period was the fact that most of the glaciers in Georgia in the 1960s were the small cirque type of glaciers, which were melted completely during the last half century [16].

In conclusion, during the last one hundred years the area of the Dolra River basin glaciers was reduced by $30.1 \%$ and their number was increased by $150.0 \%$. 


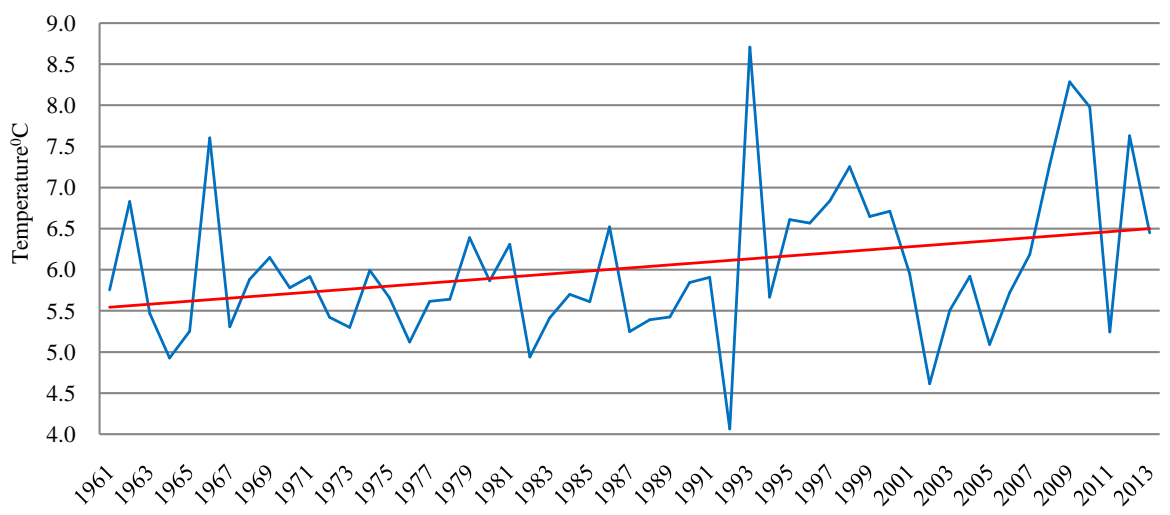

Figure 5. The course of the mean annual air temperatures of the Mestia weather station in 1961-2013.

precipitation/mm

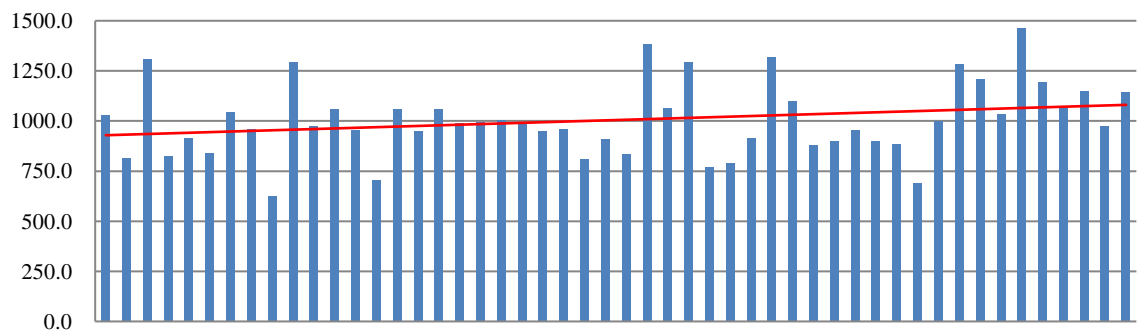

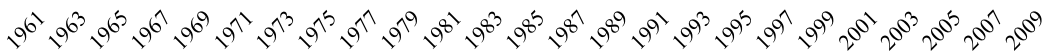

Figure 6. Sums of the annual atmospheric precipitation of the Mestia weather station in 1961-2010.

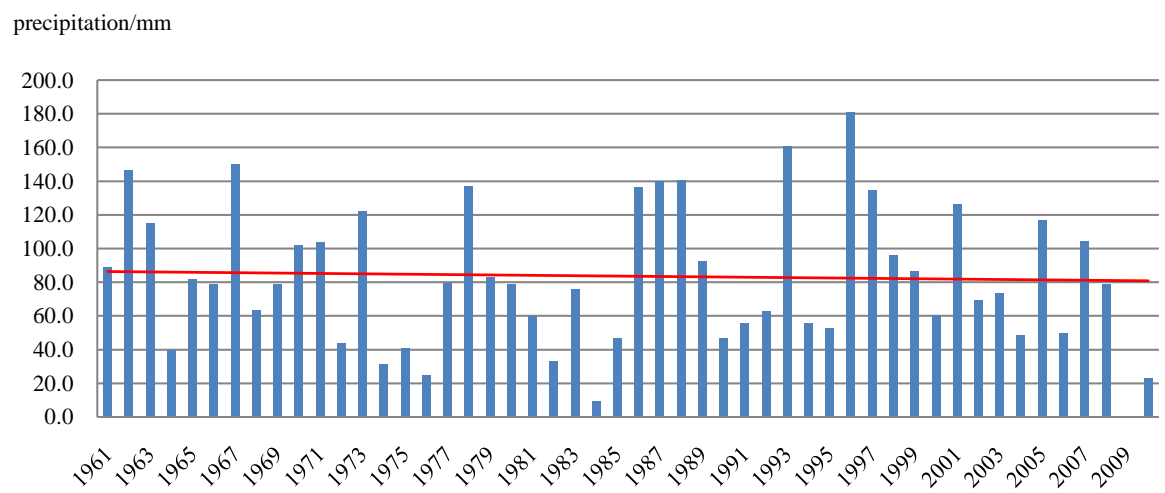

Figure 7. Sums of the December atmospheric precipitation of the Mestia weather station in 1961-2010.

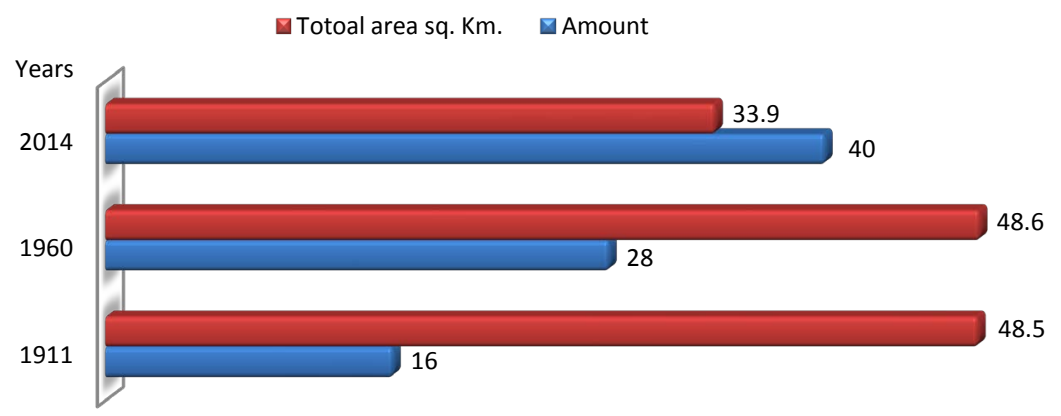

Figure 8. Changes in the number and area of the Dolra River basin glaciers in 1911-1960-2014. 


\section{Acknowledgements}

We are grateful to the Shota Rustaveli Georgian National Science Foundation for the financing our research.

\section{References}

[1] Kargel, J.S., et al. (2005) Multispectral Imaging Contributions to Global Land Ice Measurements from Space. Remote Sensing of Environment, 99, 187-219. http://dx.doi.org/10.1016/j.rse.2005.07.004

[2] Barry, R.G. (2006) The Status of Research on Glaciers and Global Glacier Recession: A Review. Progress in Physical Geography, 30, 285-306. http://dx.doi.org/10.1191/0309133306pp478ra

[3] Oerlemans, J. (2005) Extracting a Climate Signal from 169 Glacier Records. Science, 308, 675-677. http://dx.doi.org/10.1126/science.1107046

[4] Leclercq, P.W. and Oerlemans, J. (2012) Global and Hemispheric Temperature Reconstruction from Glacier Length Fluctuations. Climate Dynamics, 38, 1065-1079. http://dx.doi.org/10.1007/s00382-011-1145-7

[5] Luthi, M.P. (2014) Little Ice Age Climate Reconstruction from Ensemble Reanalysis of Alpine Glacier Fluctuations. The Cryosphere, 8, 639-650. http://dx.doi.org/10.5194/tc-8-639-2014

[6] Luthi, M.P., Bauder, A. and Funk, M. (2010) Volume Change Reconstruction of Swiss Glaciers from Length Change Data. Journal of Geophysical Research, 115, F0402. http://dx.doi.org/10.1029/2010JF001695

[7] Glasser, N.F., Harrison, S., Anderson, K.N. and Cowley, A. (2011) Global Sea-Level Contribution from the Patagonian Icefields since the Little Ice Age Maximum. Nature Geoscience, 4, 303-307. http://dx.doi.org/10.1038/ngeo1122

[8] Leclercq, P.W., Oerlemans, J. and Cogley, J.G. (2011) Estimating the Glacier Contribution to Sea-Level Rise for the Period 1800-2005. Surveys in Geophysics, 32, 519-535. http://dx.doi.org/10.1007/s10712-011-9121-7

[9] Liu, S., Sun, W., Shen, Y. and Li, G. (2003) Glacier Changes since the Little Ice Age Maximum in the Western Qilian Shan, Northwest China, and Consequences of Glacier Runoff for Water Supply. Journal of Glaciology, 49, 117-124. http://dx.doi.org/10.3189/172756503781830926

[10] Bradley, R.S., Vuille, M., Diaz, H.F. and Vergara, W. (2006) Threats to Water Supplies in the Tropical Andes. Science, 312, 1755. http://dx.doi.org/10.1126/science.1128087

[11] Moore, R.D., Flemming, S.W., Menounos, B., Wheate, R., Fountain, A., Stahl, K., Holm, K. and Jakob, M. (2009) Glacier Change in Western North America: Influences on Hydrology, Geomorphic Hazards and Water Quality. Hydrological Processes, 23, 42-61.

[12] Leclercq, P.W., Oerlemans, J., Basagic, H.J., Bushueva, I., Cook, A.J. and Le Bris, R. (2014) A Data Set of Worldwide Glacier Length Fluctuations. The Cryosphere, 8, 659-672. http://dx.doi.org/10.5194/tc-8-659-2014

[13] Meier, M.F. (1984) Contribution of Small Glaciers to Global Sea Level. Science, 226, 1418-1421. http://dx.doi.org/10.1126/science.226.4681.1418

[14] Church, J.A., Gregory, G.M., Huybrechts, P., Kuhn, M., Lambeck, K., Nhuan, M.T., Qin, D. and Woodworth, P.L. (2011) Changes in Sea Level. In: Houghton, J.T., et al., Eds., Climate Change: The Scientific Basis, Contribution of Working Group 1 to the Third Assessment Report of the Intergovernmental Panel of Climate Change, Cambridge University Press, Cambridge, 641-693.

[15] Volodicheva, N. (2002) The Caucasus. In: Shahgedanova, M., Ed., The Physical Geography of Northern Eurasia, Oxford University Press, Oxford, 350-376.

[16] Tielidze, L.G. (2014) Glaciers of Georgia. Monograph, Tbilisi, “Color”, 254 p.

[17] Tielidze, L.G., Gadrani, L. and Kumladze, R. (2015) A One Century Record of Changes at Nenskra and Nakra River Basins Glaciers, Causasus Mountains, Georgia. Natural Science, 7, 151-157. http://dx.doi.org/10.4236/ns.2015.73017

[18] Shahgedanova, M., Nosenko, G., Kutuzov, S. and Rototaeva, O. (2014) Deglaciation of the Caucasus Mountains, Russia/Georgia, in the 21st Century Observed with ASTER Satellite Imagery and Aerial Photography. The Cryosphere, 8, 2367-2379. http://dx.doi.org/10.5194/tc-8-2367-2014

[19] Tielidze, L.G., Lomidze, N. and Asanidze, L. (2015) Glaciers Retreat and Climate Change Effect during the Last One. Century in the Mestiachala River Basin, Caucasus Mountains, Georgia. Earth Sciences, 4, 72-79.

[20] Gobejishvili, R., Lomidze, N. and Tielidze, L. (2011) Late Pleistocene (Wurmian) Glaciations of the Caucasus, in Quaternary Glaciations: Extent and Chronology. In: Ehlers, J., Gibbard, P.L. and Hughes, P.D., Elsevier, Amsterdam, 141-147. http://dx.doi.org/10.1016/B978-0-444-53447-7.00012-X

[21] Upper Svaneti Adaptation Strategy to the Climate Change, 2014. UNDP, Georgia, 12. 
[22] Kotlyakov, V.M., Dyakova, A.M., Koryakin, V.S., Kravtsova, V.I., Osipova, G.B., Varnakova, G.M., Vinogradov, V.N., Vinogradov, O.N. and Zverkova, N.M. (2010) Glaciers of the Former Soviet Union. In: Williams Jr., R.S. and Ferrigno, J.G., Eds., Satellite Image Atlas of Glaciers of the World-Glaciers of Asia, US Geological Survey Professional Paper 1386-F-4.

[23] Gobejishvili, R.G. (1989) Glaciers of Georgia. Monograph, Metsniereba, Tbilisi.

[24] Podozerskiy, K.I. (1911) Glaciers of the v Caucasus Mountain Range. Zap. KORGO, 14.

[25] Tielidze, L.G., Lominadze, G. and Lomidze, N. (2015) Glaciers Fluctuation over the Last Half Century in the Headwaters of the Enguri River, Caucasus Mountains, Georgia. International Journal of Geosciences, 6, 393-401. http://dx.doi.org/10.4236/ijg.2015.64031 